\title{
Influence of practice time on surfing injuries
}

\author{
Influência do tempo de prática sobre as lesões decorrentes do surf
}

\author{
Natacha Verônica Bazanella ${ }^{[a]}$, José Guilherme Zanella D'Almeida Garrett ${ }^{[a]}$, \\ Anna Raquel Silveira Gomes ${ }^{[a, b]}$, Luiz Fernando Novack ${ }^{[b]}$, Raul Osiecki ${ }^{[b]}$, \\ Raciele Ivandra Guarda Korelo $\left.{ }^{[\mathrm{a}, \mathrm{b}}\right]^{*}$
}

[a] Universidade Federal do Paraná (UFPR), Matinhos, PR, Brasil

[b] Universidade Federal do Paraná (UFPR), Curitiba, PR, Brasil

\begin{abstract}
Introduction: studying the influence of surfing on the prevalence of injuries may contribute to prevention. Objective: to analyze the influence of time practicing sports and the occurrence of previous surgery on the profile and prevalence of injuries caused by surfing. Methods: Sixty-six Brazilian surfers (26.16 \pm 0.73 years old) participated in this study. Anthropometric data, physical activity level, surfing practice time and the prevalence of injuries (type of injury, anatomical region affected, and mechanism of injury) were evaluated. To assess which of the studied variables exerted significant influence on the mean number of injuries, a Poisson log-linear model was adjusted through R software $(p<0.05)$. Results: most surfers were classified as eutrophic $(73 \%)$, very active (60.6\%), had an average practice time of $10.1 \pm 1$ years, and were not members of a surfing federation (74\%). It was also observed that $90.9 \%$ of participants reported injuries caused by surfing and $44.9 \%$ affected the lower limbs. The majority of these injuries affected the integumentary system (46.6\%). The main mechanism of injury was impact with the board or seabed (40.4\%). Furthermore, it was found that surfing federation members presented an average of 58.4\% more injuries than non-members $(p=0.007)$.
\end{abstract}

\footnotetext{
NVB: BS, e-mail: na.bazanella13@gmail.com JGZDG: BS, e-mail: garrettfisio@gmail.com ARSG: PhD, e-mail: annaraquelsg@gmail.com LFN: PhD student, e-mail: lfnovack@hotmail.com RO: PhD, e-mail: raulfisioex@gmail.com RIGK: PhD, e-mail: raciele@ufpr.br
} 
Surfers who had undergone previous surgeries showed an average number of injuries that was $56.9 \%$ higher than other surfers $(p=0.012)$. In addition, it was found that for each extra year of surfing, the average number of injuries increased by $2.5 \%(\mathrm{p}=0.0118)$. Conclusion: the average number of injuries increased with increment in time practicing the sport, previous surgery and membership in a surfing federation.

Keywords: Injuries in Athletes. Prevalence. Sports Medicine.

\section{Resumo}

Introdução: estudar a influência da prática de surf sobre a prevalência de lesões pode contribuir para sua prevenção. Objetivo: analisar a influência do tempo de prática esportiva e realização de cirurgia prévia sobre o perfil e prevalência das lesões decorrentes do surf. Métodos: Participaram 66 surfistas brasileiros (26,16 \pm 0,73 anos). Foram avaliados os dados antropométricos, o nível de atividade física, o tempo de prática de surf e a prevalência de lesões (tipo de lesão, região anatômica acometida e o mecanismo de lesão). Para avaliar quais das variáveis estudadas exerciam influência significativa na média de lesões foi ajustado um modelo log-linear de Poisson por meio do software $R(p<0,05)$. Resultados: $A$ maior parte dos surfistas foi classificada como eutróficos (73\%), muito ativos (60,6\%), tempo médio de prática de 10,1 \pm 1 anos e não federados (74\%). Foi observado que 90,9\% dos participantes reportaram lesões decorrentes do surf, sendo que 44,9\% destas lesões acometeram os membros inferiores e a maioria atingiu o sistema tegumentar (46,6\%). O principal mecanismo de lesão foi o choque com prancha/fundo do mar (40,4\%). Ainda, verificou-se que surfistas federados apresentaram média estimada de lesões $58,4 \%$ maior que os não federados ( $p=0,007)$. Surfistas submetidos a cirurgias prévias apresentaram média estimada de lesões $56,9 \%$ maior que os demais $(p=0,012)$. Além disso, constatou-se que para cada ano a mais de prática de surf, a média estimada de lesões cresceu $2,5 \%(p=0,0118)$. Conclusão: A média estimada de lesões dos surfistas aumentou com o incremento do tempo de prática, realização de cirurgia pregressa e estar federado.

Palavras-chave: Lesões em Atletas. Prevalência. Medicina Esportiva.

\section{Introduction}

In recent years the number of surfers has increased, which has made it a popular sport worldwide $(1,2,3)$. According to the International Surfing Association, it is estimated that there are approximately 35 million surfers on the planet (4). In Brazil, the estimate is that $1.3 \%$ of the population between 14 and 75 years old (approximately 1.9 million surfers) is actively involved in this sport (5). However, despite having become very popular, scientific literature about the sport is still scarce (1), especially regarding the prevalence of injuries $(6-8)$.

The development of boards and keels with improved hydrodynamics allows for increasingly faster and more complex maneuvers, accompanied by greater physical, physiological and technical demand.
This factor may have contributed to the increased incidence of injuries in surfers $(7,8)$.

The most common injuries in surfing are contusions and injuries due to cuts, followed by sprains, muscle strains, burn and fractures. In addition, studies show that in surfing most injuries are traumatic in nature, and are mainly caused by the impact of the surfer with his own board or with the seabed, followed by the unsuccessful execution of maneuvers $(7,9)$.

In a study with surfers from the coast of Paraná (Brazil), it was verified that the most frequent type of injury in the recreational category was contusion in the lower limbs due to contact with the board (10). However, neither the physical activity level of surfers nor the influence of their practice time on the prevalence of injuries were investigated. Therefore, the objective of this study 
was to analyze whether the level of physical activity, surfing practice time, membership in a surfing federation and having undergone previous surgery influenced the type and prevalence of surfrelated injuries.

\section{Methods}

This is an observational cross-sectional analytical study (11) approved by the Research Ethics Committee in the Health Sciences Sector of the Federal University of Paraná $(335,941)$, which followed resolution 466/12 of the National Health Council and was registered in the Brazilian Registry of Clinical Trials (RBR-752vkn). All participants were informed of the procedures and gave their informed consent in writing.

For the sample size calculation, the proportion of surfers was assumed to be $1.47 \%(7,10)(2,803,770)$ of the total Brazilian population $(190,732,694)$, according to the 2010 Census data. We used the formula in (1), with a $95 \%$ confidence interval and a sampling error of $3 \%$ :

$$
N=\frac{Z_{\alpha / 2}^{2} * N^{*} P^{*}(1-P)}{\varepsilon^{2 *(N-1)+Z_{\alpha / 2}^{2} *(1-P)(1)}}
$$

Where: $n$, sample size to be calculated; $z_{\alpha / 2}^{2}$, critical value for the desired confidence level; $\mathrm{N}$, population size; P, proportion of individuals who practice surfing in Brazil; $\varepsilon^{2}$, sampling error.

Assuming such parameters, the result was 62 surfers. Thus, 66 surfers of both genders from the coast of Paraná were selected. All of them had surfed for at least 6 months, and are, aged between 18 and 42. Exclusion criteria were peripheral neurological and vascular comorbidities.

\section{Anthropometric assessment}

The anthropometric assessment was carried out through the measurement of body mass $(\mathrm{Kg})$, on a digital scale $\left(\right.$ Magna $\left.^{\circledR}\right)$, and stature $(\mathrm{cm})$, by using a 2-metre long measuring tape attached to the wall. The body mass index (BMI) was calculated dividing the body mass by the square of the stature of participants $\left(\mathrm{Kg} / \mathrm{m}^{2}\right)$, and classified according to the Health Ministry (12) as: underweight (less than $18.5 \mathrm{Kg} / \mathrm{m}^{2}$ ), eutrophic (18.5 to $24.9 \mathrm{~kg} / \mathrm{m}^{2}$ ), overweight (25 to $29.9 \mathrm{~kg} / \mathrm{m}^{2}$ ) and obese (greater than $30.0 \mathrm{~kg} / \mathrm{m}^{2}$ ).

Physical Activity Level (IPAQ-International Physical Activity Questionnaire - long form)

The level of physical activity was evaluated through a personal interview using the IPAQ long form, validated in Brazil by Matsudo et al. (13). This instrument allows to assess the intensity of the activity (walking, moderate activity and vigorous activity) and the time spent performing these activities in the week preceding the assessment. The questions referred to their activities at work and at home, such as physical activity on the way to work (for those who walk or ride their bicycles, for example), leisure time and time spent sitting (14). The results were calculated in minutes per week, following the procedural recommendations proposed by the IPAQ Core Group (15). Thus, individuals were classified according to the criteria of frequency and duration as follows: sedentary, insufficiently active, active and very active.

The surfing practice index

Each participant was interviewed and reported their surfing category (amateur, recreational or professional), time practicing the sport (in years), weekly frequency of practice (number of days) and number of hours of daily practice. For the analyses, the surfing practice index was determined through the following equation: the surfing practice index is equal to the number of hours of daily practice, multiplied by the number of days spent surfing in the week, multiplied by the number of weeks in the year, multiplied by the number of years of practice. Through the result, it was possible to classify the participants of the study according to time spent surfing: little (2999 hours/week/year), moderate (between 3000 to 5999 hours/week/year) and intense practice (over 6000 hours/week/year).

\section{Referred Morbidity Survey (RMS)}

The questionnaire was constructed based on Hoshi et al. (16), and modified according to the reality 
of the sport. The instrument aimed to gather data about injury type, body part affected, moment the surfer suffered the injury, and mechanism of injury. For the type of injury caused by the sport variable, six categories were established: integumentary (laceration and burn by a marine animal), muscular (contusion and muscle injury), bone (fractures), joint (dislocation), ligament (sprain or ligament injury), and others. The affected body parts were categorized into four segments: head, upper limbs, lower limbs and upper body. The moment when the surfer suffered one of these injuries was categorized as "during training" or "during competition". The mechanisms that prompted the injury were categorized into four types: paddling and duck diving; fall off the board (impact with the seabed and with the board); animal injury (Portuguese man o'war and jellyfish); and maneuvers. The RMS was answered through an interview, in which the participants were asked to report all injuries they had suffered during practice of the sport, taking into account all years of practice.

\section{Data analysis}

Statistical analysis was carried out with the use of R software. The data were submitted to the Kolmogorov-Smirnov test to verify the normality of distribution. Nominal and/or ordinal variables were described in absolute frequency and percentage, while the numerical variables were described in mean and standard error of the mean (SEM). In order to assess which variables exert significant influence on the mean of the surfers' injury, a log-linear Poisson model was adjusted (17). The significance level was set at $\mathrm{p}<0.05$.

\section{Results}

The sample consisted of 66 surfers, $73 \%$ of whom were eutrophic, with a predominance of practice time between 0-10 years (56\%) and a weekly frequency of $3.5 \pm 0.2$ days/week. Regarding the index of surfing practice, most surfers (65\%) were classified as having "little practice" in the recreational category. Furthermore, from all participants, 74\% were non-federated. Demographic, anthropometric and physical characteristics are listed in Table 1.
Table 1 - Demographic, anthropometric and physical characteristics of participants $(n=66)$

\begin{tabular}{|c|c|}
\hline Characteristics & Mean \pm SEM (\%) \\
\hline Age (years, mean \pm EPM) & $26.16 \pm 0.72$ \\
\hline Practice time & $10.12 \pm 1$ \\
\hline 0 to 5 years & $22(33)$ \\
\hline 5 to 10 years & $15(23)$ \\
\hline Above 10 years & $29(44)$ \\
\hline Weekly frequency (days/week) & $3.5 \pm 0.2$ \\
\hline Number of hours per day & $2.4 \pm 0.15$ \\
\hline Surfing practice index (hours/week/year) & $4998 \pm 863$ \\
\hline Little practice & $34(52)$ \\
\hline Moderate practice & $12(18)$ \\
\hline Intense practice & $20(30)$ \\
\hline \multicolumn{2}{|l|}{ Category } \\
\hline Amateur & $15(23)$ \\
\hline Recreational & $43(65)$ \\
\hline Professional & $8(12)$ \\
\hline \multicolumn{2}{|l|}{ Federated } \\
\hline Yes & $17(26)$ \\
\hline No & $49(74)$ \\
\hline \multicolumn{2}{|l|}{ Classification of BMI } \\
\hline Low weight & $4(6)$ \\
\hline Eutrophic & $48(73)$ \\
\hline Overweight & $13(20)$ \\
\hline Obese & $1(2)$ \\
\hline
\end{tabular}

Note: SEM - Standard Error of the Mean. The results reflect absolute and relative frequency (\%).

Table 2 shows the results of the International Physical Activity Questionnaire (IPAQ), in which most of the surfers were classified as very active (40\%), followed by active $(36.4 \%)$, while only $1.5 \%$ were classified as insufficiently active.

The analysis of the results obtained from the Reported Morbidity Survey, in relation to the injuries caused by surfing, showed the occurrence of at least some kind of injury along the sports career in 60 surfers (90.9\%). Among these, 14 participants (23.3\%) reported having suffered only one injury, 11 (18.3\%) reported two injuries, 15 (25\%) reported three injuries, 10 (16.6\%) reported four injuries, five (8.3\%) reported five injuries, two $(3.3 \%)$ reported six injuries, one $(1.6 \%)$ reported seven injuries and one (1.6\%) reported eight injuries, totaling $100 \%$ of injuries. Thus, an occurrence of 178 injuries was found among the 66 participants in the study. According to Table 3, considering the type of injuries, it was observed that $44.9 \%(n=80)$ of the injuries affected 
the lower limbs, $20.2 \%(\mathrm{n}=36)$ affected the upper limbs, $18.5 \%(n=33)$ affected the head and $16.3 \%(n=29)$ affected the upper body. Most of the injuries occurred in the integumentary system, representing $46.4 \%$ of cases, followed by $28.1 \%$ of muscle injuries, $14.6 \%$ of ligament injuries, with only $3.4 \%$ of joint injuries, $1.1 \%$ of bone injuries and $6.2 \%$ without a definite diagnosis.

Table 2 - Levels of physical activity of participants $(n=66)$

\begin{tabular}{lc}
\hline IPAQ & Mean \pm SEM \\
\hline Type of activity (minutes/week) & $1541.9 \pm 148.3$ \\
Work & $342.5 \pm 97.5$ \\
Transport & $285.0 \pm 38.2$ \\
\hline House & $238.2 \pm 32.6$
\end{tabular}

(To be continued)
(Conclusion)

Table 2 - Levels of physical activity of participants $(n=66)$

\begin{tabular}{lc}
\hline IPAQ & Mean \pm SEM \\
\hline Leisure & $676.0 \pm 67.8$ \\
Total per domains (minutes/week) & $1541.9 \pm 148.3$ \\
Walking & $377.5 \pm 62.8$ \\
Moderated & $666.7 \pm 63.5$ \\
$\quad$ Vigorous & $497.7 \pm 68.4$ \\
Classification & \\
(absolute and relative frequency (\%) & \\
$\quad$ Very active & $40(60.6)$ \\
Active & $24(36.4)$ \\
Active enough & $1(1.5)$ \\
\hline
\end{tabular}

Note: The results are Mean and SEM, Standard Error of the Mean.

Table 3 - bsolute and relative distribution of type of lesion by anatomical region of injury

\begin{tabular}{lccccc}
\hline & Head & Upper body & UL & LL & Total \\
\hline Integumentary & $20(11.2)$ & $9(5.1)$ & $12(6.7)$ & $42(23.6)$ & $83(46.6)$ \\
Muscle & $8(4.5)$ & $14(7.9)$ & $13(7.3)$ & $15(8.4)$ & $50(28.1)$ \\
Bone & $1(0.6)$ & $0(0)$ & $0(0)$ & $1(0.6)$ & $2(1.1)$ \\
Joint & $0(0)$ & $0(0)$ & $4(2.2)$ & $2(1.1)$ & $6(3.4)$ \\
Ligament & $0(0)$ & $0(0)$ & $7(3.9)$ & $19(10.7)$ & $26(14.6)$ \\
Other & $4(2.2)$ & $6(3.4)$ & $0(0)$ & $1(0.6)$ & $11(6.2)$ \\
Total & $33(18.5)$ & $29(16.3)$ & $36(20.2)$ & $80(44.9)$ & $178(100)$ \\
\hline
\end{tabular}

Note: UL-upper limbs. LL-lower limbs. The results are absolute and relative frequency (\%).

The most common mechanism of injury (Table 4) was found to be fall or shock with the board and/or the seabed (40.4\%), followed by maneuvers (28.1\%), paddling or "duck dive" (19.7\%) and finally contact with animals such as the Portuguese man o'war and jellyfish (11.8\%), but this prevalence distinguished among the different types of affected tissues. Most of the injuries (93.3\%) occurred during training, and only $6.7 \%$ occurred during competitions.
To evaluate the influence of the variables on the number of injuries, a log-linear Poisson model was used. Through this analysis, it was possible to ascertain which variables exert significant influence on the number of injuries and also to perform interpretations. After excluding the nonsignificant variables and verifying the quality of the adjusted data, the model described in Table 5 was determined.

Table 4 -Absolute and relative distribution of the type of lesion by mechanism of injury

\begin{tabular}{|c|c|c|c|c|c|}
\hline & Paddling & Drop and shock & Animal & Maneuver & Total \\
\hline Integumentary & $12(6.7)$ & $43(24.2)$ & $16(9.0)$ & $12(6.7)$ & $83(46.4)$ \\
\hline Muscle & $14(7.9)$ & 19 (10.7) & $1(0.6)$ & $16(9.0)$ & $50(28.1)$ \\
\hline Bone & $0(0)$ & $1(0.6)$ & $0(0)$ & $1(0.6)$ & $2(1.1)$ \\
\hline Joint & $2(1.1)$ & $3(1.7)$ & $0(0)$ & $1(0.6)$ & $6(3.4)$ \\
\hline Ligament & $4(2.2)$ & $4(2.2)$ & $0(0)$ & $18(10.1)$ & $26(14.6)$ \\
\hline Other & $3(1.7)$ & $2(1.1)$ & $4(2.2)$ & $2(1.1)$ & $11(6.2)$ \\
\hline Total & $35(19.7)$ & $72(40.4)$ & $21(11.8)$ & $50(28.1)$ & $178(100)$ \\
\hline
\end{tabular}

Note: The results are absolute and relative frequency (\%). 
Table 5 - Log-linear Poisson Model

\begin{tabular}{|c|c|c|c|c|}
\hline & Estimate & Standard error & $z$ value & $\mathrm{p}$ value \\
\hline Intercept & 0.475 & 0.139 & 3.412 & 0.0006 \\
\hline Time surfing & 0.025 & 0.010 & 2.517 & 0.0118 \\
\hline Federated & 0.460 & 0.172 & 2.667 & 0.0076 \\
\hline Surgery & 0.451 & 0.180 & 2.507 & 0.0122 \\
\hline
\end{tabular}

It is possible to see that three variables surfing time (in years), whether the surfer is a federation member, and surgery history are related to the highest average of surfers' injuries. The interpretations for this model are performed through the exponential estimation, which means that these values are interpreted as "average ratios". Thus, the estimated average of injuries is $58.4 \%$ greater among federated surfers, as opposed to non-federated ones $\left(e^{0,460}=1,584\right)$. The $95 \%$ confidence interval for this estimation was $(12.7 \%, 121.8 \%)$. Surfers who underwent surgery have an estimated average number of injuries $56.9 \%$ greater than those who did not, with a $95 \%$ confidence interval of $(9.1 \%, 121.2 \%)$. For the surfing time variable, estimation was made according to cumulative years of surfing practice. Hence, for each exceeding year of surfing, the estimated average of injuries grows $2.5 \%$, with a $95 \%$ confidence interval of $(0.5 \%, 4.5 \%)$.

This model allows for predictions of average incidence of injury expected for each athlete, using the following equation:

average number of injuries $=$ $e^{0,475+0,025 \times \text { time }+0,460 \times \text { federated }+0,451 \times \text { surgery }}$

\section{Discussion}

Popularly, surfing is a sport practiced by athletes of different ages and often associated with long periods of practice. In the present study, the average practice time among the participants of the survey was 2.4 daily hours, with a weekly frequency of 3.5 days. Moreover, 29 surfers (44\%) reported practicing the sport for over 10 years. Similar results were observed by Moraes et al. (10), who investigated the prevalence of injuries in surfers from the coast of Paraná, where the majority of participants $(47 \%)$ stated they had been surfing for 10 years or more, practicing the sport from 2 to 4 times a week (65\%), 2 to 4 hours per day (92\%). Similarly, Steinman et al. (6), when investigating the
Northeast, Southeast and South of Brazil found that their participants practiced the sport an average of 2.6 days per week, with an average duration of 2.6 hours.

In this study, the participants were subdivided into categories, with most belonging to the recreational category (65\%), followed by $23 \%$ belonging to the amateur category and only $12 \%$ to the Professional category. Moraes et al. (10) showed similar results, with $70 \%$ of the sample being recreational surfers, $28 \%$ amateurs and $2 \%$ professionals. These outcomes are supported by another study by Base et al. (7), whose also concluded that the sample was of surfers belonging to the recreational category (67\%), followed by amateurs (29\%) and professionals (3\%) of the coastal States of the Northeast, Southeast and South of Brazil.

Regarding the level of physical activity, the ACSM American College of Sports Medicine (18) - emphasizes that in order to promote and maintain health, it is necessary that healthy adults practice moderate aerobic physical activity for at least 30 minutes a day, five times a week. Alternatively, those adults can engage in intense aerobic physical activities for at least 20 minutes a day, three times a week. Most surfers in this study were categorized as very active $(60.6 \%)$ or active $(36.4 \%)$, according to IPAQ which is consistent with Romariz et al.'s study (19), in which $83.2 \%$ of the investigated surfers were classified as very active $(83.2 \%)$.

Concerning BMI, Mendez-Villanueva and Bishop (1) indicated that excessive weight can be disadvantageous when executing some specific surfing maneuvers, as well as when practicing the sport, since coordination and performance stamina may be affected. In this sense, the practice of physical exercise can directly influence the control and maintenance of body weight, as it is able to reduce the amount of fat and increase or maintain lean body mass. In our study, most surfers were classified as eutrophic (73\%), suggesting that the level of physical activity is contributing in the regulation of body mass. 
In our study, 60 out of 66 participants reported some type of injury, leading to a total of 178 injury occurrences, from the period when the practice of surfing started until the time of the survey. Taylor et al. (20), in a study conducted in Australia with 646 surfers of different levels of training, reported that 145 surfers presented 168 acute injuries over the previous 12 months, constituting 0.26 injuries per surfer in a one-year period. Another similar study (21), also conducted in Australia, indicated that out of a total of 1,348 surfers, 512 participants reported acute injuries over 12 months, totaling 739 injuries and constituting the rate of 1.79 injuries per 1,000 hours surfed. Considering this rate, surfing seems to be a relatively safe sport, since other sports, such as Australian football, has an injury rate of 25.7 injuries per 1,000 hours played (21).

Regarding the prevalence of the type of injuries, it can be seen that the majority of them occurs in the integumentary system (lacerations and burns), representing $46.6 \%$ of the cases, followed by $28.1 \%$ of muscle injuries (contusions and strains), 14.6\% of ligament injuries (sprains), 3.4\% of joint injuries (dislocations), and only $1.1 \%$ of fractures. Steinman et al. (6) reported that $44 \%$ of injuries are lacerations and $17 \%$ contusions. Similarly, Moran and Webber (22) found that lacerations (59\%) and contusions (15\%) were responsible for the majority of injuries. In Base et al. (7), most of the injuries found in professional surfers were contusions (29\%), followed by lacerations (23\%). Moraes et al. (10) showed that the prevalent type of injury was contusion (29\%). Likewise, Mitchell et al. (23) indicated that contusions comprised $25.3 \%$, while lacerations comprised $19.1 \%$ of the total number of injuries during surfing training and competition. Woodacre et al. (24) found that lacerations corresponded to $31 \%$ of the injuries, followed by contusions (24\%). In addition, Nathanson et al. (9) showed that lacerations and contusions were the second and third most common type of injury, respectively.

Among the most affected body parts, considering the type of injury, it was observed that $44.9 \%$ ( $=$ 80) of injuries affected the lower limbs, with the integumentary system being the most affected (lacerations and burns). As for the other parts, 20.2\% $(n=36)$ of injuries affected the upper limbs, with the muscle system being the most affected (contusions and strains), $18.5 \%(n=33)$ of injuries affected the head, with the integumentary system being the most affected, and $16.3 \%(\mathrm{n}=29)$ of injuries affected the trunk, with the muscle system being the most affected. Likewise, Steinman et al. (6) reported that the most frequent lacerations were in the lower limbs. Feet $(22 \%)$ and legs $(11 \%)$ were the most affected areas. Mathur et al. (10) also observed that lacerations in the feet were the most frequent ones (9\%). Nathanson et al. (9) indicated that the most common injuries in amateur surfers are lacerations on the head and on lower limbs. Moran and Webber (21) affirmed that the head was affected by injuries the most (32\%), the main cause being contusion (50\%). Furness et al. (25) reported that the lower back corresponded to $23.2 \%$ of the total chronic injuries, followed by $22.4 \%$ for the shoulders, and $12.1 \%$ for the knees, but the authors did not associate which type of injury was the most recurrent per area. Therefore, it can be suggested that the surfers on the coast of Paraná presented the same types of injuries when compared to those reported in other locations in Brazil and in the world: the most frequent injuries were lacerations and contusions, while the lower limbs were the most affected areas.

In Base et al. (8), muscle strain had a prevalence of $12.5 \%$. In Steinman et al. (7), this injury was responsible for $9.6 \%$ of total injuries. In our study, muscle strain was reported as an injury in the muscle system (along with contusions), which represents $28.1 \%$ of the total injuries, similar to the study by Furness (21), which reported that $30.3 \%$ of the injuries were in the muscle system. Therefore, the comparison with some studies is limited due to methodological criteria. Research conducted by Lowdon et al. $(26,27)$, in which sprains and strains were quantified together as muscle-ligament injuries, are examples of the limitation.

Sprain, reported as an injury in the ligament system in our study, represented $14.6 \%$ of the total injuries, with prevalence in the lower limbs. The main factor responsible for this type of injury was the maneuvers (10.1\%). In Moraes et al. (10), sprain represented 9\% of the total injuries and affected mostly the lower limbs. In their research, the maneuvers were also the main factor responsible for this type of injury ( $47 \%)$, which is similar to the findings of our study. Woodacre et al. (24) indicate that joint sprains were the third most frequent type of injury (15\%). At the same time, Taylor et al. (20) reported that this type represented $28.6 \%$ of total injuries, but Steinman et al. (6) indicated that only $6 \%$ of total injuries were joint sprains. 
Joint injuries (dislocations) occurred only in 3.4\% of the total number of injuries, as well as in Steinman et al. (6), in which dislocations were reported by 3.0\% of respondents. In Base et al. (7) and Nathanson et al. (28) no complaints of dislocations were found.

In the present study, fractures accounted for only $1.1 \%$ of all injuries and its main causative agents were the maneuvers and falling off the board, with the head and the lower limbs being the most affected body parts. These results are similar to those found in Steinman et al. (6) and Woodacre et al. (24), in which the fractures were responsible for $2.5 \%$ and $3 \%$ of the total injuries, respectively. In Base et al. (7), the fractures represent $5.4 \%$ of total injuries, similar to the $6.0 \%$ found by Nathanson et al. (28). Lowdon et al. (27) reported $9.0 \%$ of occurrence, and Taylor et al. (20) indicated 8.9\%. In all these studies, fractures were more frequent in lower limbs and had maneuvers as the main Etiologic Agent, in line with the findings of our study. On the other hand, Sano and Yotsumoto (29) have demonstrated the occurrence of single rib fractures in $50 \%$ of surfers admitted in hospital service with chest injuries, during a sixyear period, compared to $21 \%$ of people with chest injuries associated with other sports.

Integumentary system injuries (burns and lacerations), which are the most frequent type of injuries in our study, can be explained by the fact that marine animals that cause burns, like jellyfish and the Portuguese man o'war, seek warmer waters, such as the ones on the coast of Paraná. This fact was not found in the study by Lowdon et al. (27), carried out in Southeastern Australia, where the temperature of the water is cold, causing low appearance of jellyfish. In relation to lacerations, these can be attributed to contact between some part of the body and sharp structures of the board, such as the keels and the beak; or due to the impact of the surfer with the seabed or stones near the surfing site.

Muscle and ligament injuries (which are the 2nd and 3rd most frequent types of injuries in our study, respectively) may suggest predisposition to injuries of a traumatic nature due to the repetitive strain; therefore, inadequate physical preparation and the characteristics of the sport may be direct causes of these injuries. Thus, further research on the topic is needed.

We found in our study that criteria such as surfing time, whether the surfer is a member of a federation, and surgery history predict a statistically higher average of estimated injuries. For the surfing practice time variable, estimate indicated that the average number of injuries grows 2.5\% every year, demonstrating that an athlete with 25 years of practice, who is a member of a federation and has a history of surgery, will have an average of 7.4 injuries throughout their career.

Information about the average estimate of injuries presented in this study are consistent with the recommendations suggested by Steinman et al. (6), which show the importance of conducting studies to quantitatively estimate the incidence of injuries. This is important to support the development and adoption of strategies for the prevention and treatment of injuries. In this sense, the strategies can be directed from the use of protective equipment ( 6 $8,20,24)$ to the prevention of risk behavior (30), and even the insertion and adequacy of surfers' physical preparation (6). In addition, it is suggested the adoption of habits to reduce risks of injuries such as warm up exercises before surfing (10).

\section{Conclusion}

Surfers of the coast of Paraná showed a high prevalence of injuries, most of which occurred in the lower limbs and affected the integumentary system. The prevalence of injuries was influenced by factors such as higher practice time, previous surgeries, and federation membership. Therefore, we suggest the adoption of strategies to reduce the exposure of surfers to factors that predispose to injuries. In order to avoid such injuries, some of the strategies are the development and use of protective equipment, educational campaigns addressing the need of habits that reduce the risks of injury, physical preparation according to the specificities of the sport and category, and proper rehabilitation after surgical procedures, with the purpose of accelerating the return to the sport. The present study provides evidence that the aforementioned measures may be especially important for federated surfers who compete professionally.

\section{Acknowledgements}

The authors would like to thank the Statistical Laboratory (Laboratorio de estatística da UFPR, 
LABTEST) for the assistance with the statistical analysis and also the Academic Publishing Advisory Center (Centro de Assessoria de Publicação Acadêmica, CAPA - www.capa.ufpr.br) of the Federal University of Paraná for assistance with English language editing. A.R.S. Gomes is a recipient of a productivity fellowship from the CNPq (Conselho Nacional de Desenvolvimento Científico e Tecnológico, Process number 306179/2016-4).

\section{References}

1. Mendez-Villanueva A, Bishop D. Physiological aspects of surfboard riding performance. Sports Med. 2005;35(1):55-70.

2. Mendez-Villanueva A, Bishop D, Hamer P. Activity profile of world-class professional surfers during competition: A case study. J Strength Cond Res. 2006;20(3):477-82.

3. Sheppard JM, Nimphius S, Haff GG, Tran TT, Spiteri T, Brooks H, Slater G, Newton RU. Development of a comprehensive performance-testing protocol for competitive surfers. Int J Sports Physiol Perform. 2013;8(5):490-5.

4. Aguerre F. Surfing And The Olympics. International Surfing Association - ISA. [Serial on the internet] 2015 [cited 2015 Jul 2] Available from: https://tinyurl.com/ kosk6ch

5. Brasil. Ministério do Esporte. Diagnóstico Nacional do Esporte - Diesporte. Ministério do Esporte. 2015 [cited 2015 Jul 2] Available from: https://tinyurl.com/ mqpcl2j

6. Steinman J, Vasconcellos EH, Ramos RM, Botelho JL, Nahas MV. Epidemiologia dos acidentes no surfe no Brasil. Rev Bras Med Esp. 2000;6(1):9-15.

7. Base LH, Alves MAF, Martins EO, Costa RF. Lesões em surfistas profissionais. Rev Bras Med Esp. 2007;13(4):251-3.

8. Dimmick S, Gillett M, Sheehan P, Sutton C, Anderson SE. Acute injuries and chronic pathology of the head and face sustained while surf board riding. Trauma. 2014;16(3):195-201.
9. Nathanson A, Bird S, Dao L, Tam-sing K. Competitive Surfing Injuries: A Prospective Study of SurfingRelated Injuries Among Contest Surfers. Am J Sports Med. 2007;35(1):113-7.

10. Moraes GC, Guimarães ATB, Gomes ARS. Análise da prevalência de lesões em surfistas do litoral paranaense. Acta Ortop Bras. 2013;21(4):213-8.

11. Marques AP, Peccin MS. Pesquisa em fisioterapia: a prática baseada em evidências e modelos de estudos. Fisioter Pesq. 2005;11(1):43-8.

12. Brasil. Ministério da Saúde. Biblioteca Virtual em Saúde do Ministério da Saúde. Folder Obesidade. 2009 [cited 2015 May 25]. Available from: https:// tinyurl.com/nx4akrb

13. Matsudo S, Araújo T, Matsudo V, Andrade D, Andrade E, Oliveira LC, et al. Questionário Internacional de Atividade Física (IPAQ): estudo de validade e reprodutibilidade no Brasil. Rev Bras Ativ Fís e Saú. 2001;6(2):5-18.

14. Pardini R, Matsudo S, Araújo T, Matsudo V, Andrade E, Braggion G, et al. Validação do questionário internacional de nível de atividade física (IPAQ versão 6): estudo piloto em adultos jovens brasileiros. Rev Bras Ciên Mov. 2001;9(3):45-51.

15. International Physical Activity Questionnaire (IPAQ). Guidelines for data processing and analysis of the International Physical Activity Questionnaire (IPAQ) - short and long forms. 2004 [cited 2015 May 25]. Available from: http://www.ipaq. ki.se/ scoring.pdf

16. Hoshi RA, Pastre CM, Vanderlei LCM, Netto Jr J, Bastos FN. Lesões desportivas na ginástica artística: estudo a partir de morbidade referida. Rev Bras Med Esporte. 2008;14(5):440-5.

17. Magalhães MN, Lima ACP. Noções de probabilidade e estatística. 6th ed. São Paulo: USP; 2005.

18. American College of Sports Medicine (ACSM). Exercise is good for the earth, good for the body. 2007 [cited 2015 Ago 03]. Available from: https://tinyurl.com/ mts6uwc 
19. Romariz JK, Guimarães ACA, Marinho A. Qualidade de vida relacionada à prática de atividade física de surfistas. Motriz: J Phys Ed. 2011;17(3):477-85.

20. Taylor DM, Bennedett D, Carter M, Garewal D, Finch C. Perceptions of surfboard riders regarding the need for protective headgear. Wilderness Environ Med. 2005;16(2):75-80.

21. Furness J, Hing W, Walsh J, Abbott A, Sheppard JM, Climstein M. Acute Injuries in Recreational and Competitive Surfers: Incidence, Severity, Location, Type, and Mechanism. Am J Sports Med. 2015; 43 (5):1246-54.

22. Moran K, Webber J. Surfing Injuries Requiring First Aid in New Zealand, 2007-2012. Int J Aquatic Res Educ. 2013;7(3):192-203.

23. Mitchell R, Brighton B, Sherker S. The epidemiology of competition and training-based surf sport-related injury in Australia, 2003-2011. J Sci Med Sport. 2013;16(1):18-21.

24. Woodacre T, Waydia SE, Wienand-Barnett S. Aetiology of injuries and the need for protective equipment for surfers in the UK. Injury. 2015;46(1):162-5.
25. Furness J, Hing W, Abbott A, Walsh J. Retrospective analysis of chronic injuries in recreational and competitive surfers: Injury Location, Type, and Mechanism. Int J Aquatic Res Educ. 2014;8(3):277-87.

26. Lowdon BJ, Pateman NA, Pitman AJ. Surfboard-riding injuries. Med J Aust.1983;2(12):613-6.

27. Lowdon BJ, Pateman NA, Pitman AJ, Ross K . Injuries to international surfboard riders. J Sports Med Phys Fitness. 1987;27(1):57-63.

28. Nathanson A, Haynes P, Galanis D. Surfing injuries. Am J Emer Med. 2002;20(3):155-60.

29. Sano A, Yotsumoto T. Chest injuries related to surfing. Asian Cardiovasc Thorac Ann. 2015;23(7):839-41.

30. Harding AK, Stone DL, Cardenas A, Lesser V. Risk behaviors and self-reported illnesses among Pacific Northwest surfers. J Water Health. 2015;13(1):230-42.

Received in 12/07/2015 Recebido em 07/12/2015

Approved in 03/14/2017 Aprovado em 14/03/2017 